\title{
Research of the possibility of application of the superposition method for implementation of algorithms for determining damage locations in networks with isolated neutral
}

\author{
A.L. Kulikov ${ }^{I}$, V.Ju Osokin ${ }^{1, *}$, D.I. Bezdushniy ${ }^{I}$, and A.A. Loskutov ${ }^{I}$ \\ ${ }^{1}$ NSTU n.a. R.E. Alekseev, Nizhniy Novgorod, Russian Federation
}

\begin{abstract}
It is difficult to develop precise algorithms for determining fault locations for singlephase and double earth faults due to the features of emergency modes in medium voltage networks of 6-35 kV. The arbitrary configuration of electrical networks complicates the development of universal fault locations algorithms and, as a rule, technical solutions are limited by the need to use one-way measurements of emergency mode parameters. The article discusses new topology independent fault location algorithms that involve the use of the superposition method. The application of the proposed algorithms is justified by the results of simulation modeling and will allow implementation of calculating the distance to the fault in networks with isolated neutral with high accuracy.
\end{abstract}

\section{Introduction}

A long length and a high degree of wear characterize medium-voltage networks. Localization of damage requires a lot of time, and therefore accurate and rapid determination of the location of damage is an actual task.

In electric networks of $6-35 \mathrm{kV}$, as a rule, fault location methods are used, based on one-way measurement of emergency mode parameters [1-3,8-10]. The topological feature of the electrical network, the special mode of neutral grounding, as well as the lack of the possibility of multilateral measurements of emergency values, impose certain restrictions on the implementation of fault location algorithms.

Alternative technical solutions of fault location for single-phase earth faults are associated with the use of specialized indicators (for example, indicating the direction of flow of capacitive fault current, active sensing methods [4], wave fault location [13]), but the cost of such devices is quite high. The developed fault location algorithms [16] are based on one-way measurement of emergency mode parameters, imply the use of ballast resistance and show high calculation accuracy, however, they have limitations in the topology of the power transmission line.

Despite the variety of proposed hardware and software, the problem of fault location in earth faults does not have a generally accepted solution [3-12], and the proposed algorithms $[3,14,15,16]$ are not applicable to the difficult structure of the electrical network.

The article explores the use of the superposition method in order to simplify the calculated ratios and equivalence of power lines with branches for solving the problem of fault location in earth faults.

\section{Equivalent circuit analysis taking into the superposition}

Traditional fault location algorithms are based on measurement and further processing of emergency mode parameters. Emergency components contain components of purely emergency and pre-emergency (normal) modes. An urgent task is to divide the emergency mode into load and purely emergency components.

The main idea of the superposition method is to equalize the number of branches in the electrical network before and after damage. It is intended to draw up two schemes for replacing the electrical network section for normal and emergency modes. Consider the replacement scheme for double earth faults on lines that do not contain branches (Figure 1).

When drawing up the equivalent scheme for the normal mode, fictitious branch of electromotive force, value of which is equal to pre-emergency voltage at the point of damage, is included in place of proposed shortcircuit (Figure 1a). The emergency mode equivalent scheme, on the contrary, does not contain electromotive force at the place of the proposed short circuit (figure

\footnotetext{
${ }^{*}$ Corresponding author: osokin-v92@mail.ru
} 
1b). Subtracting according to Kirchhoff's laws from the equations of the emergency scheme, the equations of the pre-emergency mode, we obtain a purely emergency

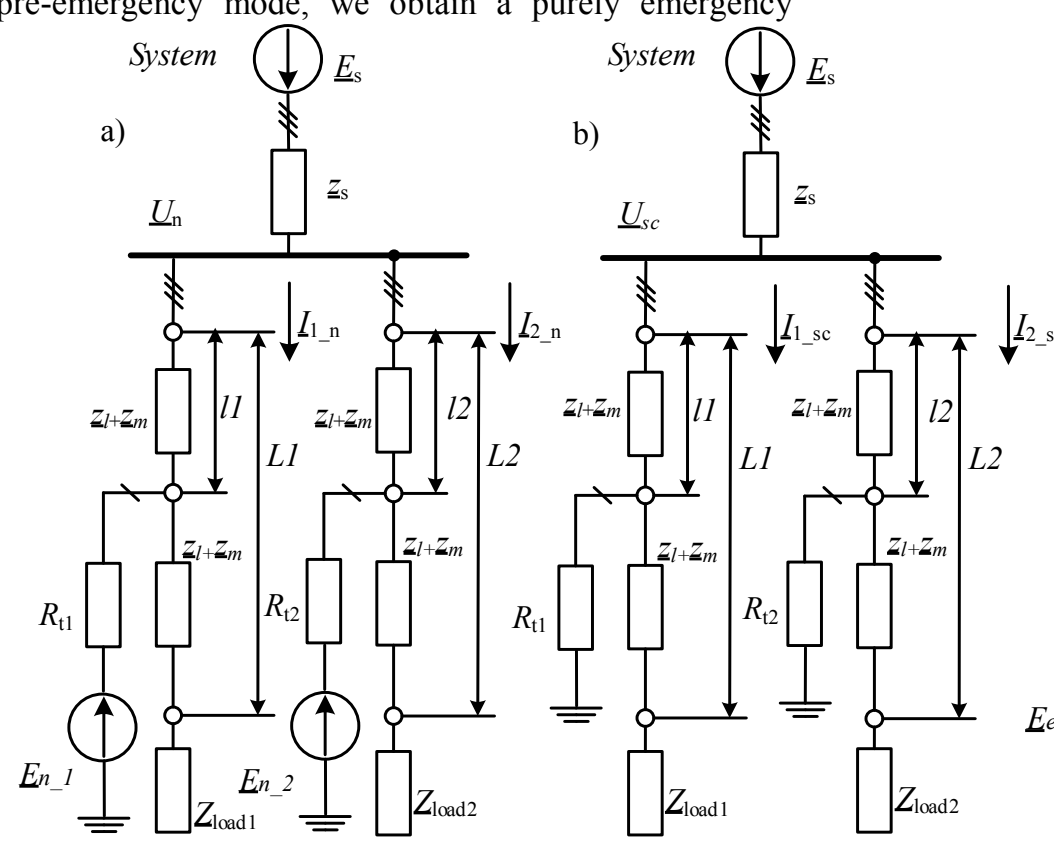

Fig. 1. Explanation of the application of the superposition method

Let us present the equivalent circuit for a purely emergency mode in a three-phase version (figure 2).

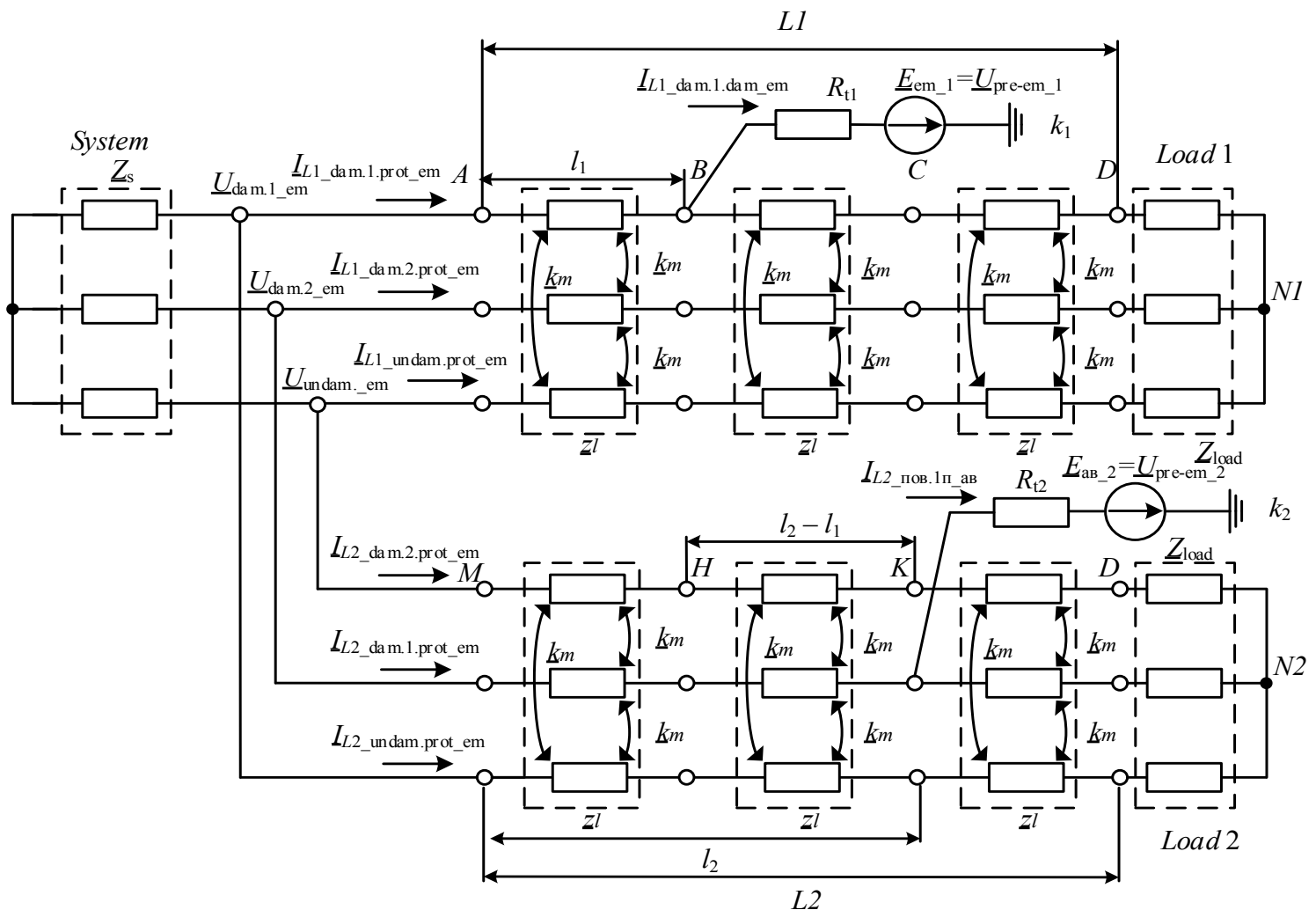

Fig. 2. Replacement scheme for a purely emergency mode in three-phase design

Analysis [7] of the scheme shown in Figure 2 in phase coordinates allows obtaining calculated expressions for determination of distances to points of damage.

Pre-emergency voltages at the point of damage (figure 2) are determined by the expression: scheme (figure 1c), that contains in an undistorted form all the necessary information for recognizing damage.

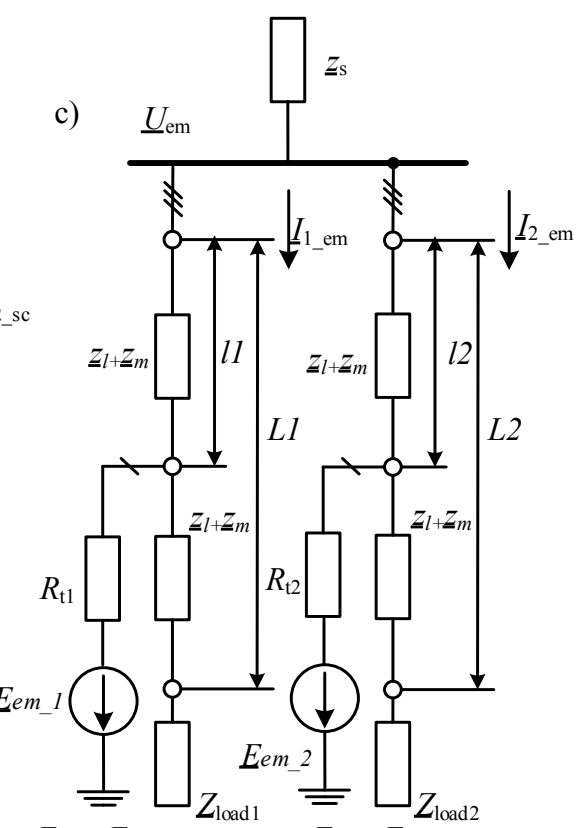

$E_{n} 1=E_{e m+1}$ $E_{n} 2=E_{\text {em }} 2$ 
where $l_{x}$ - the actual distance to point of damage; $\underline{Z}_{m \_} x$ - resistivity of mutual induction; $\underline{Z}_{l_{-} x}$ - line resistivity; $\underline{U}_{y_{-} z}-$ the phase voltage of the corresponding mode; $\underline{I}_{x_{-} y \text {.prot }} z$ - the current flowing at the location of the protection; $\underline{I}_{x_{-} y . d a m_{-} z}-$ current flowing at the point of damage; index «X» indicates the analyzed line (1-line $L 1,2$ - line $L 2$ ); index «yy» indicates the phase (dam.1- the damaged phase of the analyzed line, dam.2- the damaged phase of the nearby line, undam-undamaged phase); index «z» corresponds to the mode ( $\mathrm{n}$ - normal mode, sk - emergency mode, em - purely emergency mode).
In the case of the purely emergency scheme (figure 2 ), the influence of the load component is reduced. In case of short circuits at points $k 1$ и $k 2$, the electromotive force at the point of damage is determined by the following expression:

$$
\begin{aligned}
& \underline{E}_{e m_{-} x}=-\underline{U}_{\text {dam.1_em }}+\underline{I}_{x_{-} \text {dam.1. prot_em }} \cdot Z_{l_{-} x} \cdot l_{x}+ \\
& +\left(\underline{I}_{x_{-} \text {dam.2.protem }}+\underline{I}_{x_{-} \text {undam. prot_em }}\right) \cdot Z_{m_{-}} \cdot l_{x}+\underline{I}_{x_{-} \text {dam.1.1dam_em }} \cdot R_{t 1}
\end{aligned}
$$

In accordance with the superposition method, the electromotive force at the point of damage $\underline{E}_{e m_{-} x}$ is equal to the emergency value, therefore, taking into account the expressions (1) and (2) obtain the following expression:

$$
\begin{aligned}
& \underline{U}_{\text {dam.1_em }}+\underline{U}_{\text {dam.1 } 1_{-} n}=l_{x} \cdot\left(\underline{I}_{x_{-} \text {dam.2.prot.em }}+\underline{I}_{x_{-} \text {undam.prot_em }}+\underline{I}_{x_{-} \text {dam.2.prot. } n}+\underline{I}_{x_{-} \text {undam.prot } n}\right) \cdot Z_{m_{-} x}+ \\
& +l_{x} \cdot\left(\underline{I}_{x_{-} \text {dam.1.prot_n}}+\underline{I}_{x_{-} \text {dam.1.1.prot_em }}\right) \cdot Z_{l_{-} x}+\underline{I}_{x_{-} \text {dam.1.dam_em }} \cdot R_{t 1} .
\end{aligned}
$$

Since the transition resistance is active, its influence components. Expressing the line length from the relation can be excluded by considering only the reactive

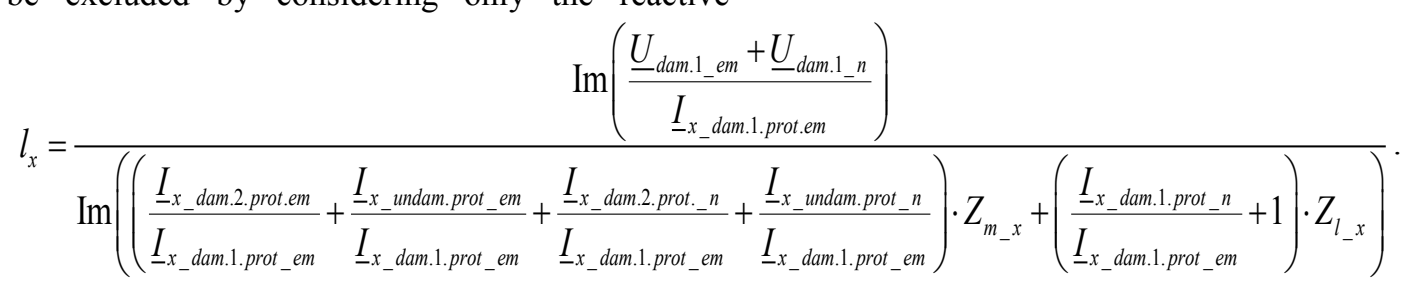

Expression (4) is universal and allows you to determine the distance not only to the near and far points of power line damage in double earth faults, but also in single-phase earth faults, for methods involving the use of ballast resistance [16].

\section{Results of the modelling}

The study of the developed fault location method was implemented in the Matlab software complex and the Simulink modeling environment. Damage simulation was carried out on a model of a section of the electric network containing power lines with distributed parameters and assuming a given set of configurations (figure 3).

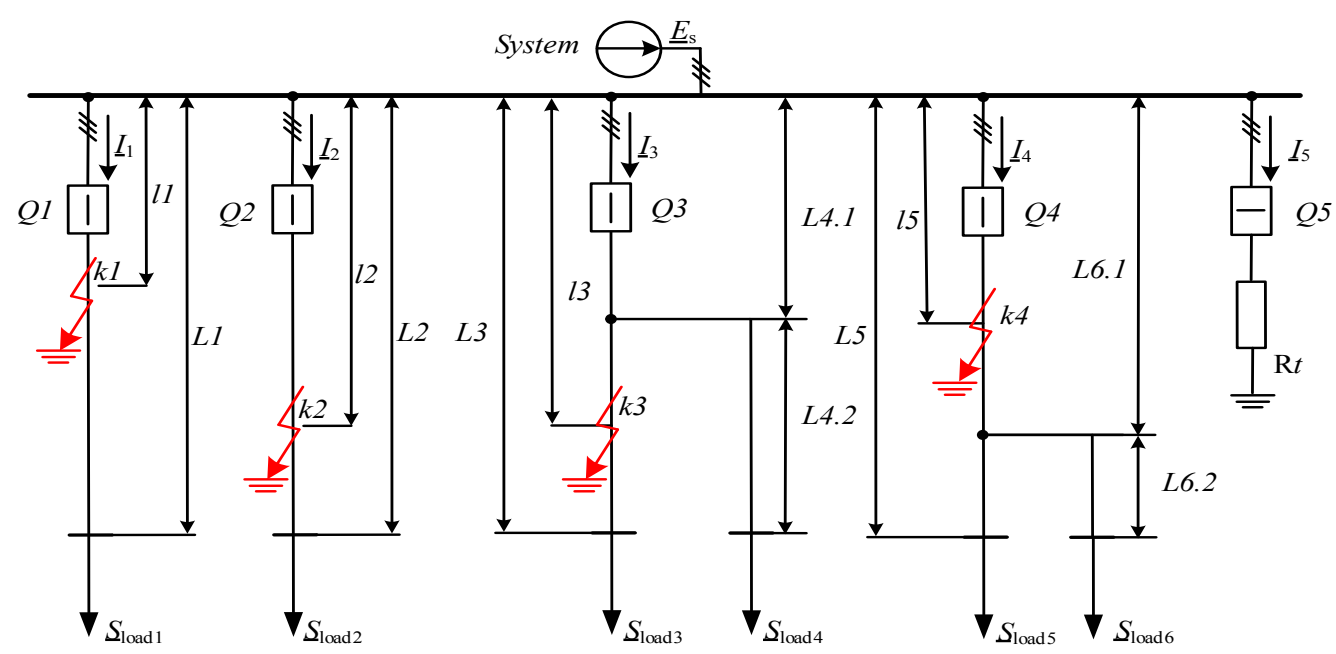

Fig. 3. The considered scheme of the electric network section

The considered scheme has the following parameters: length of lines: $L_{1}=20 \mathrm{~km}, L_{2}=20 \mathrm{~km} ; L_{3}=$ $25 \mathrm{~km} ; L_{4.1}=10 \mathrm{~km} ; L_{4.1}=5 \mathrm{~km} ; L_{4.2}=10 \mathrm{~km} L_{5}=30$ $\mathrm{km} ; L_{6.1}=20 \mathrm{~km} ; L_{6.2}=10 \mathrm{~km}$; specific resistance of the phase: $\underline{Z}_{l}=0.083+j 0.695 \mathrm{Ohm} / \mathrm{km}$; specific resistance of mutual induction: $\underline{z}_{m}=0.0485+j 0.3517 \mathrm{Ohm} / \mathrm{km}$; 
transient resistances $R t$ in the places of closures are determined by a random quantity distributed with uniform law in the range from 0 to $20 \mathrm{Ohms}$; load power consumption: $\quad \underline{S}_{\text {load }}=37.2+j 15.4 \mathrm{MVA}, \quad$ that corresponds to resistance $\underline{z}_{\text {load }}=28.13+j 11.640 \mathrm{~m}$.

During the simulation, the following assumptions were made:

1) the three-phase elements of the system are assumed to be symmetrical;

2) the transition resistance is purely active;

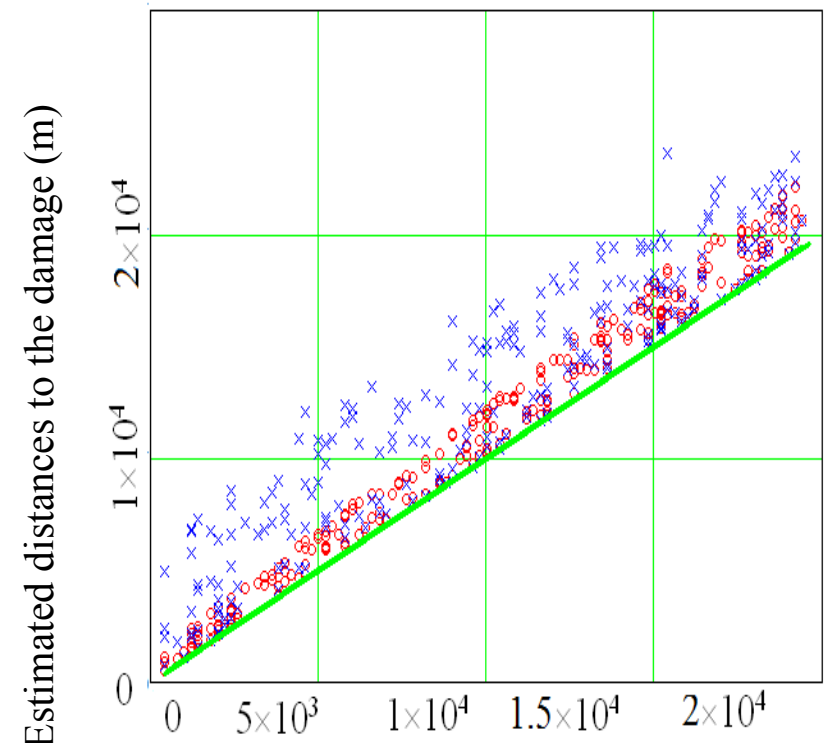

a) Actual distances to the damage (m)
3) the type of damage and damaged phases are known.

Processing the simulation results allowed us to obtain the dependence of the calculated distances on the actual values (figure 4, figure 5). Comparison of calculation results (expression (4)) with values calculated by algorithms [15,16] using emergency mode parameters was carried out to analyze the advantages of the proposed algorithm.

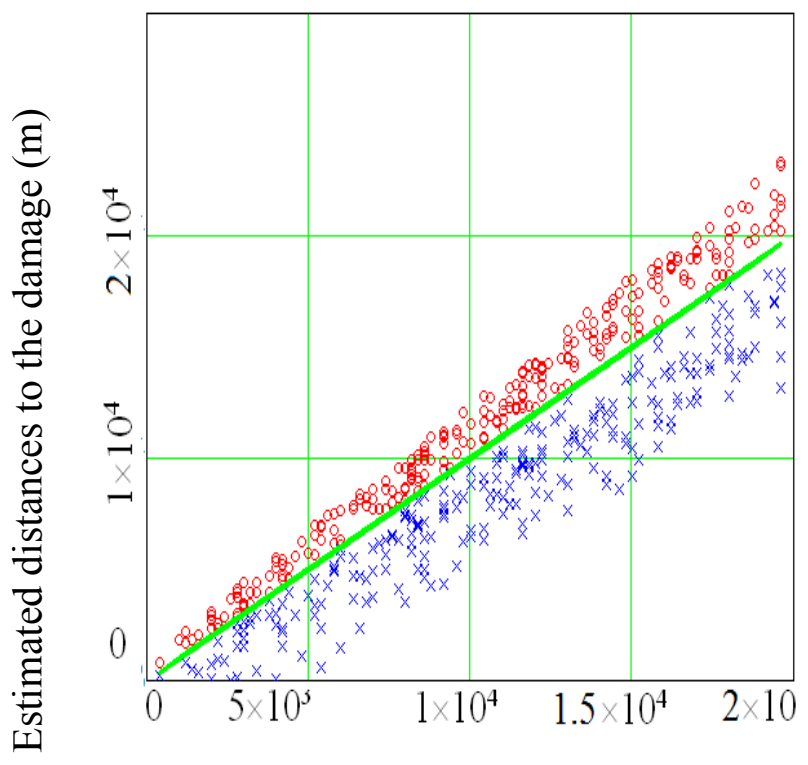

b) Actual distances to the damage (m)

Fig. 4. Dependence of the calculated distances to the points of damage from the actual ones for double earth faults on power lines without branches

Figure 4 shows the calculated dependences for double earth faults on lines without branches, obtained using the purely emergency scheme (the circle on the diagram), and the parameters of the emergency mode (the cross on the diagram). Analysis of the results shows that the use of a purely emergency mode can significantly reduce the deviation of the calculated distances from the actual ones. In comparison with the algorithms using parameters of the emergency mode [15], the proposed version of fault location algorithms allows to reduce the maximum value of relative error from $45 \%$ to $16 \%$.

The double earth fault at point $\mathrm{k} 3$ (short circuit before the branch) and at point $\mathrm{k} 4$ (short circuit after the branch) (figure 1) was simulated to justify the advantages of using the developed fault location algorithm on lines with branches.

The calculated values according to the fault location algorithms, based on the use of emergency mode parameters $[15,16]$ and the presence of power lines branches, have a relative error of up to $50 \%$ (the cross on the figure 5). The use of the purely emergency mode in the fault location procedure allows reducing the maximum value of the relative error in calculating the distance to the damage site to $15 \%$ (the circle on the figure 5). Reducing the size of errors is achieved by reducing the influence of current distribution on lines with branches, as well as the load component when introducing the purely emergency mode. 


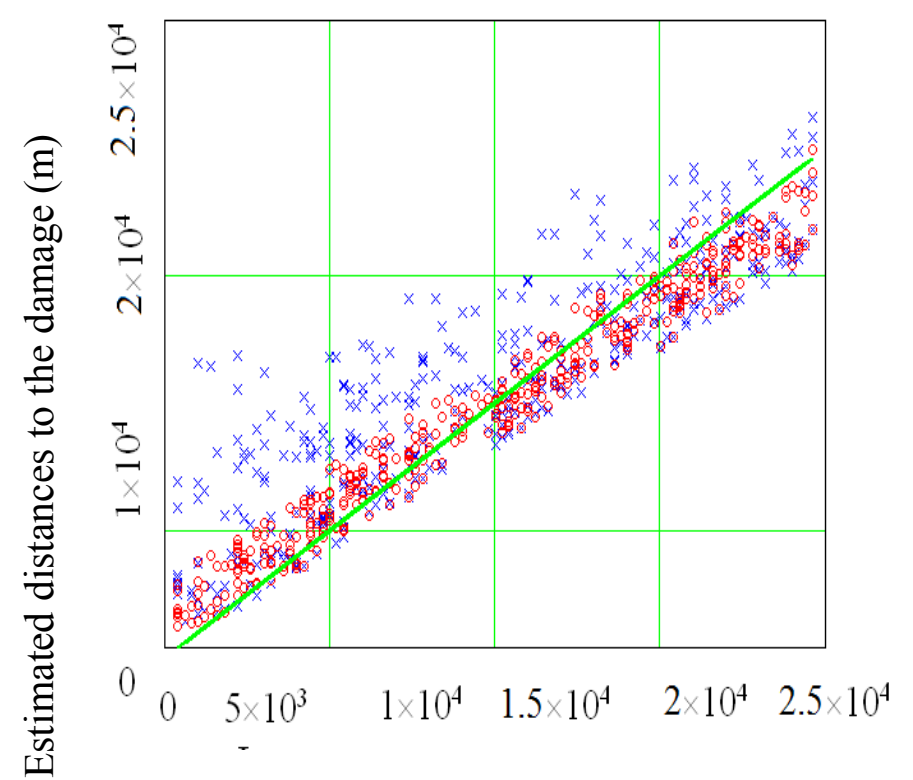

a) Actual distances to the damage (m)

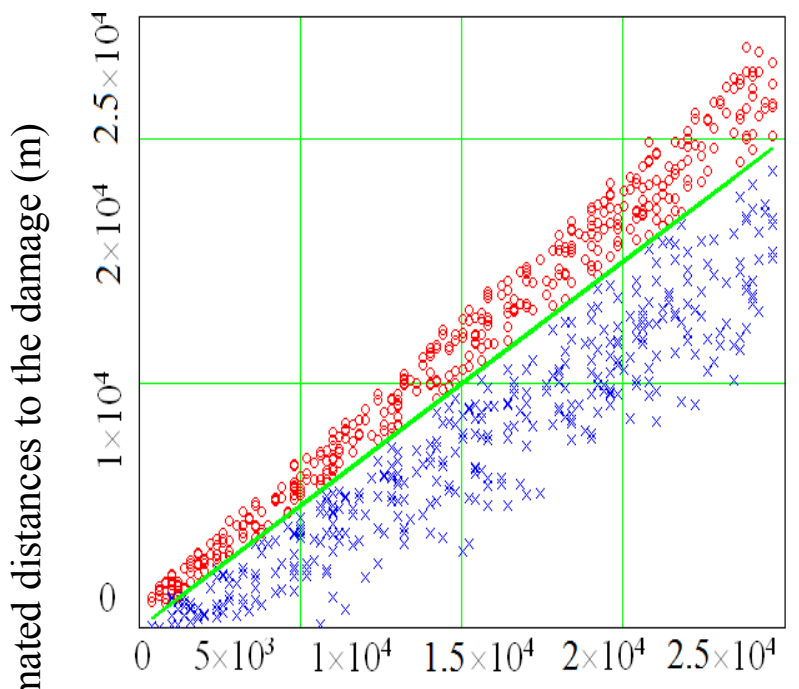

b) Actual distances to the damage (m)

Fig. 5. Dependence of the calculated distances to the points of damage from the actual ones for double earth faults on power lines with branches

Similar results were obtained in the simulation and application of the developed algorithm of the fault location (expression (4)) in case of single-phase earth faults [16].

\section{Conclusions}

1. It is promising to use the superposition method to form fault location algorithms for single-phase and double earth faults in distribution electric networks. The method reduces the influence of current distribution on power lines with branches as well as the load component on the accuracy of fault distance calculation.

2. The simulation modeling result of the $35 \mathrm{kV}$ electric network section showed the significant (more than threefold) reduction of the error in calculating the distance to the damage and the corresponding reduction in the power line bypass zone in case of double and single-phase earth faults.

The reported study was funded by RFBR, project number 19-38-90144.

\section{References}

1 V.A. Shuin, G.A. Filatova, T.Yu. Shadrikova, E.S. Hagurina. Sposob opredeleniya mesta odnofaznogo zamykaniya fidera na zemlyu $\mathrm{v}$ kabel'nyh setyah srednego napryazheniya // Elektrooborudovanie: ekspluataciya i remont, pp.62-71, 10 (2019)

2 E.A. Vorob'eva, D.I. Gandzhaev, G.A. Filatova, V.A. Shuin, Informatsionnye parametry elektricheskikh velichin perekhod-nogo protsessa dlya opredeleniya mesta zamykaniya na zemlyu $\mathrm{v}$ raspredelitel'nykh kabel'nykh setyakh napryazheniem 6-10 kV, Vestnik IGEU, pp.34-42 (2017)

3 E.F. Khakimzyanov, R.G. Mustafin, A.I. Fedotov, Opredelenie rasstoyaniy do mest dvoynykh zamykaniy na zemlyu na linii elektroperedachi raspredelitel'noy seti srednego napryazheniya, Izvestiya vuzov, Problemy energetiki, pp.132-137 (2015)

4 A. L. Kulikov, M. Sh. Misrikhanov, A. A. Petrukhin, Opredelenie mest povrezhdeniy LEP $6-35 \mathrm{kV}$ metodami aktivnogo zondirovaniya, - M.: Energoatomizdat, P.162 (2009)

5 A.N. Visyashchev, Diagnostika sostoyaniya vozdushnykh liniy elektroperedachi $10-110 \mathrm{kV} \mathrm{v}$ normal'-nykh i avariynykh rezhimakh, IrGTU, Uchebnoe posobie, P. 270 (2012)

6 Geoinformatsionnaya sistema OMP 6-35 kV. URL: www.relematika.ru (data obrashcheniya: 17.07.2017) www.relematika.ru/produkty/635_kv/sistema_omp_6-35_kv.

7 B.V. Papkov, $\quad$ V.YU. Vukolov. Elektroenergeticheskie sistemy i seti. Toki korotkogo zamykaniya: 3-e izd., pererab. i dop. - M.: Izdatel'stvo YUrajt, P. 353 (2018)

8 Yu. S. Belyakov, Aktual'nye voprosy opredeleniya mest povrezhdeniya vozdushnykh liniy elektroperedachi, Bibliotechka energetika, prilozhenie k zhurnalu «Energetik», 11, P.80 (2010)

9 A.L. Kulikov, M.D. Obalin, P.A. Kolobanov, Kompleksnye algo-ritmy OMP LEP na baze statisticheskikh metodov, Energetik, 1 (2012)

10 A. L. Kulikov, M. D. Obalin, P. A. Kolobanov, Analiz i povyshenie tochnosti pri opredelenii mesta 
povrezhdeniya liniy elektroperedachi, Izvestiya vuzov. Elektromekhanika, 5, pp.57-62 (2013)

11 H. Diaz, M. López, Fault location techniques for electrical distribution networks: a literature survey, in Proc. the Fifth IASTED International Conference, pp. 311-318 (2005)

12 M. Lehtonen, Novel techniques for fault location in distribution networks, in Proc. Power Quality and Supply Reliability Conference, pp. 1-6 (2008)

13 A.L. Kulikov, V.V. Anan'ev, Adaptivnoe volnovoe opredelenie mesta povrezhdeniya linii ehlektroperedach, Vestnik IGEU, 1.4, pp.21-25 (2014)

14 A.L. Kulikov., M. D. Obalin, V.Ju. Osokin, T.R. Sharafeev, Primenenie imitacionnogo modelirovaniya LEP 6-35 kV dlya povysheniya tochnosti opredeleniya rasstoyaniya do dvojnyh zamykanij na zemlyu, Vestnik IGEU, 1, pp.40-49 (2018)

15 A.L. Kulikov., V.Ju. Osokin, D.I. Bezdushnyj, A.A. Petrov, Povyshenie tochnosti algoritmov opredeleniya mesta povrezhdeniya LEP 6-35 kv pri dvojnyh zamykaniyah na zemlyu s pomoshch'yu vvedeniya iteracionnyh procedur, Elektroenergiya, peredacha i raspredelenie, 1, pp.54-59 (2019)

16 A.L. Kulikov, V.Ju. Osokin, D.I. Bezdushnyj, A.A. Petrov, Primenenie kratkovremennogo dvojnogo zamykaniya na zemlyu dlya realizacii algoritma opredeleniya mesta povrezhdeniya LEP $6-35 \mathrm{kV}$ pri odnofaznyh zamykaniyah na zemlyu // Elektroenergiya, peredacha i raspredelenie, pp.36-41 2 (2020) 